IRSTI $31.21 .25 ; 76.31 .35$

\author{
${ }^{1}$ L. Figueroa-Valverde, ${ }^{2} \mathrm{M}$. Rosas-Nexticapa, \\ ${ }^{3} \mathrm{~F}$. Díaz-Cedillo, ${ }^{1} \mathrm{~T}$. Lopez-Gutierez, ${ }^{1} \mathrm{M}$. López-Ramos, \\ ${ }^{1}$ L.Hau-Heredia, ${ }^{2}$ E. Pool-Gómez, ${ }^{2}$ P. Hernandez-Vasquez \\ ${ }^{1}$ Laboratory of Pharmaco-Chemistry, Faculty of Chemical Biological Sciences, University Autonomous \\ of Campeche, Av. Agustín Melgar s/n, Col Buenavista C.P. 24039 Campeche, Camp., México. \\ ${ }^{2}$ Facultad de Nutrición, Universidad Veracruzana, Médicos y Odontologos s/n C.P. 91010 , \\ Unidad del Bosque Xalapa Veracruz, México. \\ ${ }^{3}$ Escuela Nacional de Ciencias Biológicas del Instituto Politécnico Nacional. \\ Prol. Carpio y Plan de Ayala s/n Col. Santo Tomas, México, D.F. C.P. 11340. \\ *e-mail: lfiguero@uacam.mx; lauro_1999@yahoo.com
}

\title{
Synthesis and theoretical activity evaluation of a new steroid-oxazolone derivative against COX1-1 and COX-2
}

\begin{abstract}
There are some reports for the preparation of several drugs as COX-inhibitors; however, some reagents used in the preparation are expensive and difficult to handle. The aim of this study was to synthesize a steroid-oxazolone derivative using some reactions such as $i$ ) hydroxylation-amiination; ii) amidation; iii) alkynyl-addition; $i v$ ) aldolization and $i v$ ) imination. In addition, a theoretical assessment was carried out to evaluate the interaction of both COX-1 and COX-2 with the steroid-oxazolone derivative using indomethacin and rofecoxib as controls in a docking model. The structure of the compounds obtained was confirmed through elemental analysis, spectroscopy and spectrometry data. The results showed that the steroid-oxazolone derivative has a higher affinity for COX 1 compared to indomethacin; however, it exhibits a lower affinity for COX-2 in comparison with rofecoxib. These data suggest that the steroid-oxazolone derivative could be a good candidate as COX-1 inhibitor translated as a possible drug for treatment of pain. Key words: inhibitor, hydroxylation-amiination, amidation, alkynyl-addition.
\end{abstract}

\section{Introduction}

For years, several inhibitors of the enzyme cyclooxygenase have been used for the treatment of both inflammation and pain such as ketorolac, naproxen, acetylsalicylic acid, paracetamol ibuprofen, indomethacin $[1,2]$ and others. However, some of these drugs can produce side effects such as bronchospam, vasomotor thinitis, and angioedema [3], renal dysfunction, meningeal syndrome, and bone marrow depression, headache, vertigo, [4-6]. In the search of other alternative therapeutics for treatment of these clinical pathologies, several drugs have been prepared such as 1-morpholinocyclohexanecarbonitrile from both morpholine and cyclohexanone [7]. Other data showed the reaction of Ethyl 5-(4-nitrophenyl) furan-2-carboxylate with hydrazine to form 5-(4-nitrophenyl) furan-2-carbohydrazide [8]. In addition, a series of 3-(4-biphenyl)-5-substituted phenyl2-pyrazolines were synthesized from both chalcones and hydrazine with biological activity to pain [9]. Also, a study showed the synthesis of 4-aminopiperidine derivative with analgesic activity through of reaction of (1-Benzylpiperidin-4-yl)-[2-(3,4-dimethoxyphenyl)ethyl]-amine with 5-bromo-2-(3,4dimethoxyphenyl)-2-(methylethyl) pentanenitrile [10]. All these data indicate that some methods are available for synthesis of drugs with analgesic activity; nevertheless, expensive reagents and special conditions are required. Therefore, the aim of this study was to synthesize a steroid-oxazolone derivative for evaluating their theoretical activity evaluation against both COX1-1 (2OYU) and COX-2 (3LN1) [11] using a docking model.

\section{Material and Methods}

\section{General methods}

2-nitroestrone was prepared using a previously method reported [12]; in addition, the others reagents 
used in this investigation were acquired from SigmaAldrich Co., Ltd. The melting point for compounds was determined on an Electrothermal (900 model). Infrared spectra (IR) were recorded using $\mathrm{KBr}$ pellets on a Perkin Elmer Lambda 40 spectrometer. ${ }^{1} \mathrm{H}$ and ${ }^{13} \mathrm{C}$ NMR spectra were recorded on a Varian VXR300/5 FT NMR spectrometer at $300 \mathrm{MHz}$ in $\mathrm{CDCl}_{3}$ using TMS as internal standard. EIMS spectra were obtained with a Finnigan Trace Gas Chromatography Polaris Q-Spectrometer. Elementary analysis data were acquired from a Perkin Elmer Ser. II CHNS/02400 elemental analyzer.

\section{Chemical Synthesis}

(13S)-3-((1-hydroxyethyl)amino)-13-methyl2-nitro-6, 7,8,9,11,12,13,14,15,16-decahy-dro-17Hcyclopenta[a]phenanthren-17-one (2)

In a round bottom flask $(10 \mathrm{ml}), 2$-nitroestrone (200 $\mathrm{mg}, 0.63 \mathrm{mmol})$ and acetonitrile $(5 \mathrm{ml})$ were stirred to reflux for $12 \mathrm{~h}$. The solution obtained was reduced pressure and purified through a crystallization using the methanol:water $(4: 1)$ system; yielding $44 \%$ of product; m.p. $166-168{ }^{\circ} \mathrm{C}$; IR $\left(\mathrm{V}_{\max }, \mathrm{cm}^{-}\right.$ 1) $3430,3400,1712$ and $1544:{ }^{1} \mathrm{H}$ NMR $(500 \mathrm{MHz}$, Chloroform- $d$ ) $\delta_{\mathrm{H}}: 0.90(\mathrm{~s}, 3 \mathrm{H}), 1.20-1.34(\mathrm{~m}, 4 \mathrm{H})$, $1.44(\mathrm{~s}, 3 \mathrm{H}), 1.54-2.46(\mathrm{~m}, 8 \mathrm{H}), 3.02-3.10(\mathrm{~m}, 3 \mathrm{H})$, $5.60(\mathrm{~m}, 1 \mathrm{H}), 6.56(\mathrm{~m}, 1 \mathrm{H}), 7.72$ (broad, $2 \mathrm{H}), 8.42$ (m, 1H) ppm. ${ }^{13} \mathrm{C}$ NMR (500 MHz, Chloroform- $d$ ) $\delta_{\mathrm{C}}: 13.82,21.70,24.90,25.50,27.55,28.94,31.06$, $35.00,37.25,46.43,48.34,50.12,76.62,115.44$, 124.70, 128.92, 137.2, 141.00, 147.80, $219.74 \mathrm{ppm}$. EI-MS m/z: 358.18. Anal. Calcd. for $\mathrm{C}_{20} \mathrm{H}_{26} \mathrm{~N}_{2} \mathrm{O}_{4}$ : C, 67.02; H, 7.31; N, 7.82; O, 17.85. Found: C, 67.00; H, 7.24.

$\left(\begin{array}{lll}1 & 2 a S)-8,12 a-d i m e t h y l-\end{array}\right.$ 2,3,3a,3b,4,5,7,8,10b,11,12,12a-dodecahydro-1H-cyclopenta [7,8]phenanthro[2,3-d]oxazol-1-one (3)

In a round bottom flask $(10 \mathrm{ml})$, compound 2 (200 mg, $0.58 \mathrm{mmol}$ ), potassium carbonate $(45 \mathrm{mg}$, $0.33 \mathrm{mmol}$ ), and $5 \mathrm{ml}$ of dimethyl sulfoxide were stirred to reflux for $12 \mathrm{~h}$. The solution obtained was reduced pressure and purified through a crystallization using the methanol:water:hexane $(4: 1: 1)$ system; yielding $67 \%$ of product; m.p. $122-124{ }^{\circ} \mathrm{C}$; IR $\left(\mathrm{V}_{\max }, \mathrm{cm}^{-1}\right)$ 3432, 1710 and 1210: ${ }^{1} \mathrm{H}$ NMR (300 MHz, Chloroform- $d$ ) $\delta_{\mathrm{H}}: 0.90(\mathrm{~s}, 3 \mathrm{H}), 1.18(\mathrm{~s}, 3 \mathrm{H})$, 1.22-1.90 (m, 7H), 2.10-3.10(m, 8H), $6.24(\mathrm{~m}, 1 \mathrm{H})$, 6.43-6.54 (m, 2H), 7.22 (broad, 1H) ppm. ${ }^{13} \mathrm{C}$ NMR (300 MHz, Chloroform- $d$ ) $\delta_{C}: 13.80,19.91,21.82$, $25.84,27.55,28.92,31.50,35.40,37.56,46.90$, $48.12,50.40,83.50,107.22,110.92,131.32,133.26$,
136.02, 144.00, 220.70 ppm. EI-MS m/z: 311.18. Anal. Calcd. for $\mathrm{C}_{20} \mathrm{H}_{25} \mathrm{NO}_{2}: \mathrm{C}, 77.14 ; \mathrm{H}, 8.09 ; \mathrm{N}$, 4.50; O, 10.28. Found: $\mathrm{C}, 77.10 ; \mathrm{H}, 10.19$.

(12aS)-7-(2-chloroacetyl)-8,12a-dimethyl$2,3,3 a, 3 b, 4,5,7,8,10 b, 11,12,12 a$-dodecahydro- $1 \mathrm{H}$ cyclopenta[7,8]phenanthro [2,3-d]oxazol-1-one (4)

In a round bottom flask $(10 \mathrm{ml})$, compound 3 (200 mg, $0.64 \mathrm{mmol})$, chloroacetyl chloride $(50 \mu 1$, $0.63 \mathrm{mmol})$ and triethylamine $(100 \mu 1,0.71 \mathrm{mmol})$ in $5 \mathrm{~mL}$ of methanol was stirring for $72 \mathrm{~h}$ to room temperature. The solution obtained was reduced pressure and purified through a crystallization using the methanol:water (4:2) system; yielding 54\% of product; m.p. $136-138{ }^{\circ} \mathrm{C}$; IR $\left(\mathrm{V}_{\max }, \mathrm{cm}^{-1}\right) 1712$, 1632 and 1210: ${ }^{1} \mathrm{H}$ NMR (300 MHz, Chloroformd) $\delta_{\mathrm{H}}: 0.90(\mathrm{~s}, 3 \mathrm{H}), 1.22-1.36(\mathrm{~m}, 4 \mathrm{H}), 1.40(\mathrm{~s}, 3 \mathrm{H})$, 1.55-2.20 (m, 7H), 2.46-2.62 (m, 4H), 3.92-4.00 (m, $2 \mathrm{H}), 6.40(\mathrm{~m}, 1 \mathrm{H}), 6.73-7.30(\mathrm{~m}, 2 \mathrm{H}) \mathrm{ppm} .{ }^{13} \mathrm{C} \mathrm{NMR}$ (300 MHz, Chloroform- $d$ ) $\delta_{\mathrm{C}}: 13.80,19.90,21.74$, $25.70,27.63,28.92,31.32,35.30,37.45,42.42$, $46.87,48.10,50.22,82.84,109.40,116.23,133.00$, 134.00, 135.40, 152.97, 160.82, 220.30 ppm. EI-MS $\mathrm{m} / \mathrm{z}$ : 387.16. Anal. Calcd. for $\mathrm{C}_{22} \mathrm{H}_{26} \mathrm{ClNO}_{3}$ : C, 68.12; H, 6.76; Cl, 9.14, N, 3.61; O, 12.37. Found: C, 68.06; H, 6.70 .

(12aS)-7-(7-hydroxyhept-2-ynoyl)-8,12a-dimethyl-2,3,3a,3b,4,5,7,8,10b,11,12,12a-dodecahydro-1H-cyclopenta $[7,8]$ phenanthro [2,3-d]oxazol1-one (5)

In a round bottom flask $(10 \mathrm{ml})$, compound 4 (310 mg, $0.80 \mathrm{mmol})$, 5-hexyn-1-ol (90 $\mu 1,0.82$ mmol) and Copper(II) chloride $(110 \mu 1,0.82 \mathrm{mmol})$ in $5 \mathrm{~mL}$ of methanol was stirring for $72 \mathrm{~h}$ to room temperature. The solution obtained was reduced pressure and purified through a crystallization using the methanol:water (4:1) system; yielding 65\% of product; m.p. $106-108{ }^{\circ} \mathrm{C}$; IR $\left(\mathrm{V}_{\max }, \mathrm{cm}^{-1}\right) 3400$, 2196, 1712, 16390 and 1212: ${ }^{1} \mathrm{H}$ NMR (300 MHz, Chloroform- $d$ ) $\delta_{\mathrm{H}}: 0.90(\mathrm{~s}, 3 \mathrm{H}), 1.22-1.36(\mathrm{~m}, 4 \mathrm{H})$, $1.40(\mathrm{~s}, 3 \mathrm{H}), 1.55(\mathrm{~m}, 1 \mathrm{H}), 1.58-1.72(\mathrm{~m}, 4 \mathrm{H}), 1.80-$ $1.90(\mathrm{~m}, 2 \mathrm{H}), 1.94$ (broad, $1 \mathrm{H}), 2.10-2.20(\mathrm{~m}, 4 \mathrm{H})$, 2.25-2.26 (m, 2H), 2.46-2.62 (m, 4H), 3.62-(m, $2 \mathrm{H})$, $6.40(\mathrm{~m}, 1 \mathrm{H}), 6.60-7.40(\mathrm{~m}, 2 \mathrm{H}) \mathrm{ppm} .{ }^{13} \mathrm{C} \mathrm{NMR}$ (300 MHz, Chloroform- $d$ ) $\delta_{\mathrm{C}}: 13.80,17.62,19.00$, $21.74,25.71,25.75,27.60,28.92,30.04,31.35$, $35.32,37.42,46.87,48.10,50.24,62.05,73.96$, $82.95,90.12,109.52116 .02,133.10,133.92,135.40$, 149.62, 152.82, $220.30 \mathrm{ppm}$. EI-MS m/z: 435.24. Anal. Calcd. for $\mathrm{C}_{27} \mathrm{H}_{33} \mathrm{NO}_{4}: \mathrm{C}, 74.45 ; \mathrm{H}, 7.64 ; \mathrm{N}$, 3.22; O, 14.69. Found: C, 74.40; H, 7.60 
$8-((12 a S)-8,12 a$-dime thyl-1-oxo2,3,3a,3b,4,5,10b,11,12,12a-decahydro-1H-cyclopenta [7,8]phenanthro[2,3-d]oxazol-7(8H)-yl)8-oxooct-6-ynal (6)

In a round bottom flask $(10 \mathrm{ml})$, compound 5 (200 mg, $0.46 \mathrm{mmol}$ ) $5 \mathrm{~mL}$ of dimethyl sulfoxide was stirring for $72 \mathrm{~h}$ to reflux. The solution obtained was reduced pressure and purified through a crystallization using the methanol:water:hexane $(4: 1: 1)$ system; yielding $48 \%$ of product; m.p. $116-118^{\circ} \mathrm{C}$; IR $\left(\mathrm{V}_{\max }, \mathrm{cm}^{-1}\right) 2194,1726,1710$ and 1210: ${ }^{1} \mathrm{H}$ NMR (300 MHz, Chloroform- $d$ ) $\delta_{\mathrm{H}}: 0.90(\mathrm{~s}, 3 \mathrm{H}), 1.22-1.36$ (m, 4H), $1.40(\mathrm{~s}, 3 \mathrm{H}), 1.55(\mathrm{~m}, 1 \mathrm{H}), 1.70-1.76(\mathrm{~m}$, $4 \mathrm{H}), 1.80-2.10(\mathrm{~m}, 4 \mathrm{H}), 2.12(\mathrm{~m}, 1 \mathrm{H}), 2.13-2.14(\mathrm{~m}$, $2 \mathrm{H}), 2.20-2.54(\mathrm{~m}, 3 \mathrm{H}), 2.56(\mathrm{~m}, 2 \mathrm{H}), 2.62-2.63(\mathrm{~m}$, $2 \mathrm{H}), 6.40(\mathrm{~m}, 1 \mathrm{H}), 6.60-7.40(\mathrm{~m}, 2 \mathrm{H}), 9.70(\mathrm{~d}, 1 \mathrm{H}, \mathrm{J}$ $=1.00 \mathrm{~Hz}) \mathrm{ppm} \cdot{ }^{13} \mathrm{C}$ NMR $(300 \mathrm{MHz}$, Chloroformd) $\delta_{\mathrm{C}}: 13.80,18.15,19.00,21.70,22.10,25.71,25.76$, 27.62, 28.93, 31.34, 35.32, 37.42, 44.57, 46.86, 48.10, $50.22,73.97,82.97,91.32,109.52,116.02,133.10$, 133.92, 135.40, 149.61, 152.82, 202.44, $220.30 \mathrm{ppm}$. EI-MS m/z: 447.24. Anal. Calcd. for $\mathrm{C}_{27} \mathrm{H}_{33} \mathrm{NO}_{4}$ : C, 75.14; H, 7.43; N, 3.13; O, 14.30. Found: C, 75.10; H, 7.38.

(12aS)-7-((1Z,4E)-1,4-diazacyclododeca4,12-dien-6-yn-5-yl)-8,12a-dimethyl-2,3,3a, $3 b, 4,5,7,8,10 b, 11,12,12 a$-dodecahydro- $1 \mathrm{H}$-cyclopenta [7,8]phenanthro[2,3-d]oxazol-1-one (7)

In a round bottom flask $(10 \mathrm{ml})$, compound $\mathbf{6}$ (200 mg, $0.45 \mathrm{mmol})$, ethylenediamine ( $50 \mu \mathrm{l}, 0.74$ $\mathrm{mmol}$ ) and boric acid (50 mg, $0.80 \mathrm{mmol})$ in $5 \mathrm{~mL}$ of methanol was stirring for $72 \mathrm{~h}$ to room temperature. The solution obtained was reduced pressure and purified through a crystallization using the methanol:water (4:1) system; yielding $65 \%$ of product; m.p. 146-148 ${ }^{\circ} \mathrm{C}$; IR $\left(\mathrm{V}_{\max }, \mathrm{cm}^{-1}\right) 3322,2196$, 1712 and 1212: ${ }^{1} \mathrm{H}$ NMR (300 MHz, Chloroform- $d$ ) $\delta_{\mathrm{H}}: 0.85(\mathrm{~m}, 1 \mathrm{H}), 0.90(\mathrm{~s}, 3 \mathrm{H}), 1.22-1.36(\mathrm{~m}, 4 \mathrm{H})$, $1.46(\mathrm{~m}, 2 \mathrm{H}), 1.55(\mathrm{~m}, 1 \mathrm{H}), 1.57(\mathrm{~s}, 3 \mathrm{H}), 1.58(\mathrm{~m}$, $2 \mathrm{H}), 1.80-2.20-2.54(\mathrm{~m}, 6 \mathrm{H}), 2.30(\mathrm{~m}, 2 \mathrm{H}), 2.46-$ $3.10(\mathrm{~m}, 4 \mathrm{H}), 4.30-4.50(\mathrm{~m}, 1 \mathrm{H}), 6.60(\mathrm{~m}, 1 \mathrm{H})$, $6.70(\mathrm{~m}, 1 \mathrm{H}), 6.80(\mathrm{~m}, 1 \mathrm{H}), 6.88(\mathrm{~m}, 1) \mathrm{ppm} .{ }^{13} \mathrm{C}$ NMR (300 MHz, Chloroform- $d$ ) $\delta_{\mathrm{C}}: 13.80,19.42$, $19.91,21.70,23.03,25.70,27.64,28.60,28.92$, $31.34,34.44,35.32,34.44,46.85,48.10,48.42$, $50.00,50.24,88.44,91.53,97.96,108.65,115.12$, $131.70,132.66,133.45,145.46,149.72,159.86$, $220.30 \mathrm{ppm}$. EI-MS m/z: 471.28. Anal. Calcd. for
$\mathrm{C}_{30} \mathrm{H}_{37} \mathrm{~N}_{3} \mathrm{O}_{2}: \mathrm{C}, 76.40 ; \mathrm{H}, 7.91 ; \mathrm{N}, 8.91 ; \mathrm{O}, 6.78$. Found: C, 76.34; H, 7.88.

\section{Physicochemical parameters evaluation}

Some electronic parameters such as HOMO (Highest Occupied Molecular Orbital), LUMO (Lowest Unoccupied Molecular Orbital) energy, orbital coefficients distribution, molecular dipole moment and HBD (hydrogen bond donor groups) and HBA (hydrogen bond acceptor groups) and PSA (polar surface area) were evaluated using the SPARTAN'06 software [13].

\section{Pharmacophore evaluation}

The 3D pharmacophore model for the compounds 6 and 7 was determinate using LigandScout 4.08 software [14]

Theoretical evaluation of the interaction between compound 4 and kinase-2 protein (3FL5).

The interaction of compound 4 with both COX11 (2OYU) and COX-2 (3LN1) [11] was carried out using a DockingServer [15].

\section{Results and Discussion}

Several oxazolone analogs have prepared using some reagents such as $\left[\left(\mathrm{Ph}_{3} \mathrm{P}\right) \mathrm{Au}(\mathrm{NCMe})\right] \mathrm{Sb}_{6}$ complex [16], N,N'-terephthaloylbis-( $d l$-alanine) [17], resin [18], $\mathrm{Ph}_{3} \mathrm{P}-\mathrm{CBr}_{4}$ adducts [19], palladium [20] and others. In this study, a steroid-oxazolone derivative was prepared using some strategies; the first stage was achieved via reaction of 2-nitroestrone with acetonitrile to form an amino-ethanol complex (Figure 1 and 2).

The ${ }^{1}$ HNMR showed several signals for 2 at $0.90 \mathrm{ppm}$ for methyl group bound to steroid nucleus; at $1.44 \mathrm{ppm}$ for methyl bound to both hydroxyl and methylamine; at 1.20-1.34, 1.54-3.10, 6.56 and $8.42 \mathrm{ppm}$ for steroid moiety; at $5.60 \mathrm{ppm}$ for methylene group bound to both amino and hydroxyl groups; at 7.72 for both hydroxyl and amine groups. The ${ }^{13} \mathrm{CNMR}$ display some signals at $13.82 \mathrm{ppm}$ for methyl group; at 24.90 for methyl bound to both hydroxyl and methylamine; at 21.70, 25.50-50.12 and 115.44-147.80 ppm for steroid moiety; at 76.62 ppm for methylene group bound to both amino and hydroxyl groups; at $219.70 \mathrm{ppm}$ for ketone group. In addition, the mass spectrum from 2 showed a molecular ion $(\mathrm{m} / \mathrm{z}) 358.18$. 


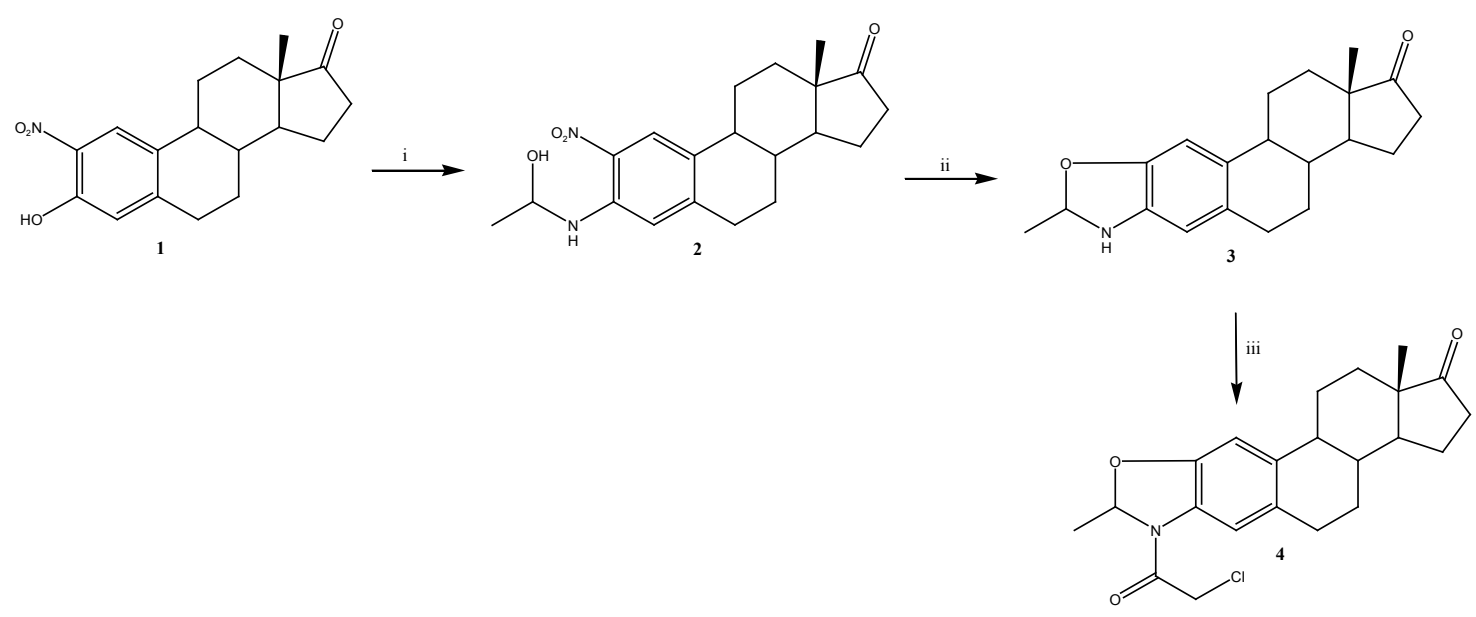

Reaction of 2-nitroestradiol with acetonitrile (i) to form a hydroxyethylamino-nitro-estrone (3). Then, an steroid oxazolone (3) via displacement of nitro group by hydroxyl in $\mathrm{DMSO} / \mathrm{K}_{2} \mathrm{CO}_{3}$ (ii) presence of reacted with. Finally, 3 reacted with chloroacetyl chloride (iii) to form 4

Figure 1 - Preparation of a chloroacetyl-steroid-oxazolone derivative (4).

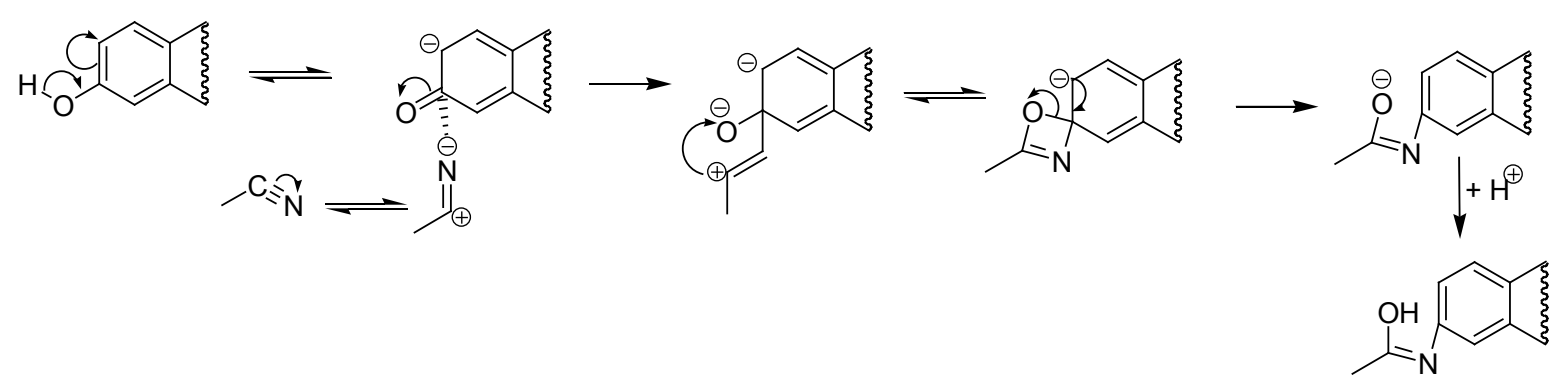

Figure 2 - Mechanism of reaction involved in the synthesis of hydroxyethylamino-nitro-estrone

The second stage was achieved by the synthesis of an ether-steroid derivative (3); it is important to mention that some reports have been reported for the preparation of ether derivatives via displacement of nitro group using methoxide as dipolar aprotic solvent $[21,22]$. In this study, 3 was prepared using a previously method reported [12]; the reaction was carried out through intramolecular displacement from nitro group by the hydroxyl group of compound 2 in presence of $\mathrm{DMSO} / \mathrm{K}_{2} \mathrm{CO}_{3}$ (Figure 1). The ${ }^{1} \mathrm{HNMR}$ showed several signals for 3 at $0.90 \mathrm{ppm}$ for methyl group bound to steroid nucleus; at $1.18 \mathrm{ppm}$ for methyl bound to oxazole ring; at 1.22-3.10 and 6.43$6.54 \mathrm{ppm}$ for steroid moiety; at $6.24 \mathrm{ppm}$ for oxazole ring; at 7.72 for both hydroxyl and amine groups. The ${ }^{13} \mathrm{CNMR}$ display some signals at $13.80 \mathrm{ppm}$ for methyl group; at 19.91 for methyl bound to oxazole ring; at 21.82-50.40 and 107.22-144.00 ppm for steroid moiety; at 83.50 for oxazole ring; at $220.70 \mathrm{ppm}$ for ketone group. Finally, the mass spectrum from 3 showed a molecular ion $(\mathrm{m} / \mathrm{z}) 311.18$.

Int. j. biol. chem. (Online)
On the other hand, a chloroamide-steroid derivative (4) was prepared; it is important to mention that there are many procedures for the formation of chloroamides which are known in the literature, for example the reaction of amine with trichloroisocyanuric Acid [23] or amide secondary with $\mathrm{N}$-chlorobenzotriazole to form a chloroamide derivative [24]; in addition, have been prepared some chloroamide groups using chloroacetyl chloride [25]. The ${ }^{1} \mathrm{HNMR}$ showed several signals for 4 at $0.90 \mathrm{ppm}$ for methyl group bound to steroid nucleus; at 1.40 ppm for methyl bound to oxazole ring; at 1.22-2.62 and 6.73-7.30 ppm for steroid moiety; at 3.92-4.00 $\mathrm{ppm}$ for methylene group of chloroamide; at 6.40 ppm for oxazole ring. The ${ }^{13} \mathrm{CNMR}$ display some signals at $13.80 \mathrm{ppm}$ for methyl group; at 19.90 for methyl bound to oxazole ring; at 21.74-37.45, 46.87-50.22, 109.40-152.97 ppm for steroid moiety; at $42.42 \mathrm{ppm}$ methylene group of chloroamide; at 88.84 for oxazole ring; at $160.82 \mathrm{ppm}$ for amide group; at $220.30 \mathrm{ppm}$ for ketone group. Addition- 
ally, the mass spectrum from $\mathbf{4}$ showed a molecular ion $(\mathrm{m} / \mathrm{z}) 387.16$.

The following stage involves the synthesis of a propargylic-amide derivative (5). It is noteworthy that several propargylic-amide analogs have been prepared [26, 27]; however, some reagents are dangerous and are difficult to handle. Therefore in this study, 5 was prepared via addition 5-hexyn-1-ol to 4 in presence of Copper(II) chloride (Figure 2) using a previously method report [27]. The ${ }^{1} \mathrm{HNMR}$ showed several signals for $\mathbf{5}$ at $0.90 \mathrm{ppm}$ for methyl group bound to steroid nucleus; at $1.40 \mathrm{ppm}$ for methyl bound to oxazole ring; at 1.22-1.36, 1.55, 1.80-1.90, $2.10-2.20,2.46-2.62$ and $6.60-7.40 \mathrm{ppm}$ for steroid moiety; at1.58-1.72, 2.26 and $3.62 \mathrm{ppm}$ for arm bound to both alkyne and hydroxyl groups; at 1.94 ppm for hydroxyl group; at $6.40 \mathrm{ppm}$ for oxazole ring. The ${ }^{13} \mathrm{CNMR}$ display some signals at $13.80 \mathrm{ppm}$ for methyl bound to steroid nucleus; at $19.90 \mathrm{ppm}$ for methyl bound to oxazole ring; at 17.62, 25.78, 30.04, $62.05,109.50-135.40$ and $152.82 \mathrm{ppm}$ for arm bound to both alkyne and hydroxyl groups; at 21.74-25.71, 27.60-28.92 and 31.35-50.24 ppm for steroid moiety; at 73.96 and $90.12 \mathrm{ppm}$ for both alkyne group; at 82.95 for oxazole ring; at $119.62 \mathrm{ppm}$ for amide group; at $220.30 \mathrm{ppm}$ for ketone group. Additionally, the mass spectrum from $\mathbf{5}$ showed a molecular ion $(\mathrm{m} / \mathrm{z}) 435.24$.

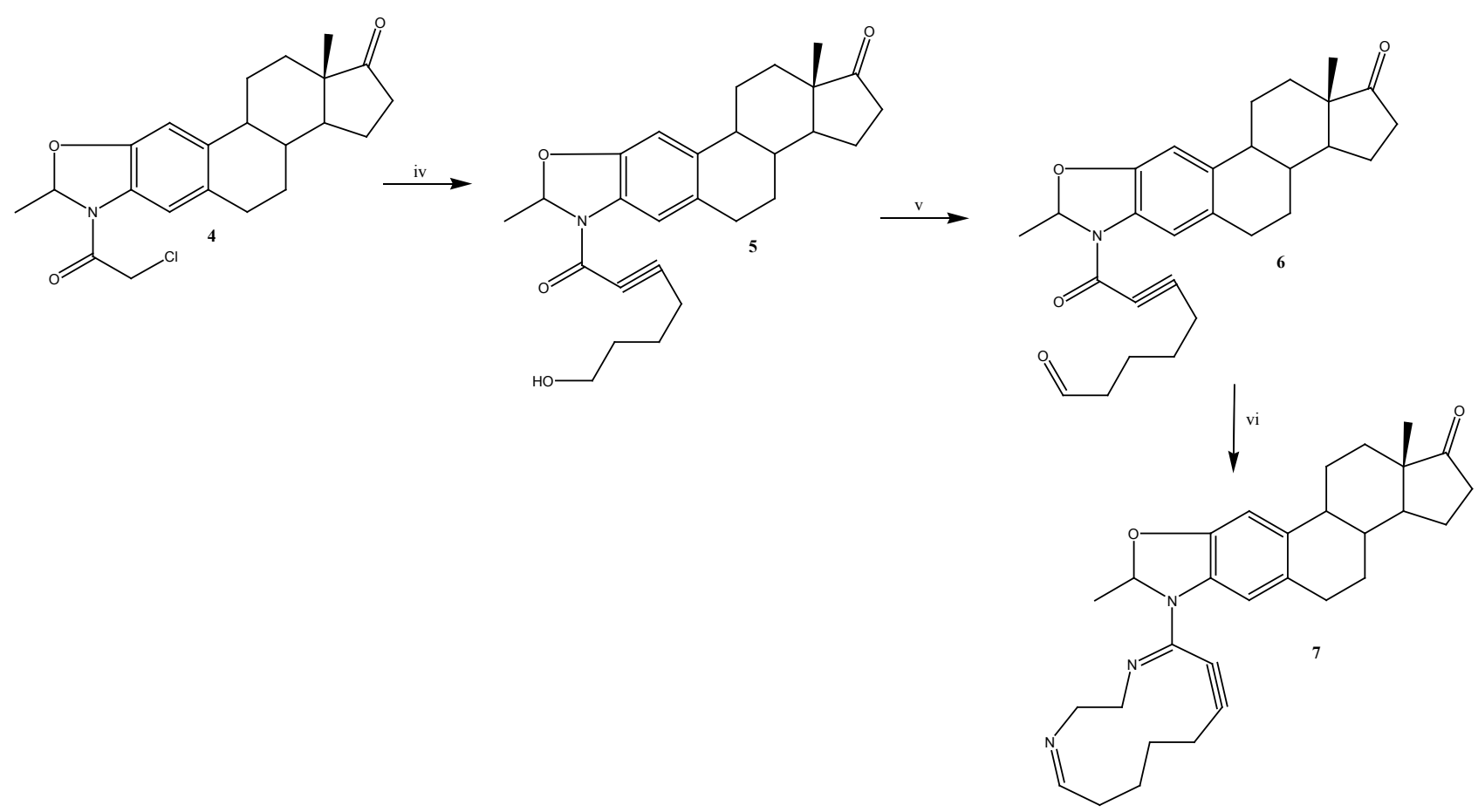

Reaction of chloroacetyl-steroid-oxazolone derivative (4) with 5-hexyn-1-ol to form hydroxyhept-2-ynoyl)-steroid-oxazolone (5) in presence of Copper(II) chloride (iv). Then, an oxazol-steroid-8-oxooctynal (6) was prepared via reaction of 5 with dimethyl sufuxide (v). Finally, 6 reacted with ethylenediamine to form 7

Figure 3 - Synthesis of 1,4-diazacyclododeca-4,12-dien-6-yn-5-yl-steroid-oxazolone (7).

In addition, 5 was reacted with dimethyl sulfoxide to form an aldehyde-oxazolone-steroid derivative using a previously method reported for synthesis of aldehyde groups [28]. The ${ }^{1}$ HNMR showed several signals for 6 at $0.90 \mathrm{ppm}$ for methyl group bound to steroid nucleus; at $1.40 \mathrm{ppm}$ for methyl bound to oxazole ring; at 1.22-1.36, 1.54, 1.80-2.10, 21.3, 2.202.54, 2.62-2.63 and 6.60-7.40 ppm for steroid moiety; at 1.70-1.76, 2.12-2.14 and $2.56 \mathrm{ppm}$ for arm bound to both alkyne and hydroxyl groups; at $1.94 \mathrm{ppm}$

Int. j. biol. chem. (Online) for hydroxyl group; at $6.40 \mathrm{ppm}$ for oxazole ring; at $9.70 \mathrm{ppm}$ for aldehyde group. The ${ }^{13} \mathrm{CNMR}$ display some signals at $13.80 \mathrm{ppm}$ for methyl bound to steroid nucleus; at $19.90 \mathrm{ppm}$ for methyl group bound to oxazole ring; at 18.15, 22.10, 25.76, 44.57 for arm bound to both aldehyde and alkyne group; at 21.70 , $25.71,27.62-37.42,46.86-50.22,109.52-135.40$ and $152.82 \mathrm{ppm}$ for steroid moiety; at 73.97 and 91.32 ppm for alkyne group; at 82.97 ppm for oxazole ring; at $208.44 \mathrm{ppm}$ for aldehyde group; at $220.30 \mathrm{ppm}$ for 
ketone group. In addition, the mass spectrum from 6 showed a molecular ion $(\mathrm{m} / \mathrm{z})$ 447.24.

Finally, an 1,4diaza-cyclododeca-4,12-dien6-yne ring was prepared via reaction of $\mathbf{6}$ with ethylenediamine to form imino groups of the 1,4-diazacyclododeca-4,12-dien-6-yn-5-yl-steroid-oxazolone (7). The ${ }^{1} \mathrm{HNMR}$ showed several signals for 7 at 0.88 , $1.46,2.30,4.30-4.50$ and $6.70 \mathrm{ppm}$ for 1,4-diazacyclododeca-4,12-dien-6-yne ring; at $0.90 \mathrm{ppm}$ for methyl group bound to steroid nucleus; at $1.58 \mathrm{ppm}$ for methyl bound to oxazole ring; at 1.22-1.36, 1.55, $1.80-2.10,2.46-3.10,6.60$ and $6.80 \mathrm{ppm}$ for steroid moiety; at $6.88 \mathrm{ppm}$ for oxazole ring. The ${ }^{13} \mathrm{CNMR}$ display some signals at $13.80 \mathrm{ppm}$ for methyl bound to steroid nucleus; at $19.91 \mathrm{ppm}$ for methyl bound to oxazole ring; at 19.42, 23.03, 28.60, 34.44 and 48.42-50.00 ppm for 1,4diaza-cyclododeca-4,12dien-6-yne ring; at 21.70, 25.70-27.64, 28.92-31.34, 35.32-48.10. 50.24 and 108.65-145.46 ppm for steroid moiety; at $91.53 \mathrm{ppm}$ for oxazole ring; at $149.72-159.86 \mathrm{ppm}$ for imino group; at $220.30 \mathrm{ppm}$ for ketone group. Finally, the mass spectrum from 7 showed a molecular ion (m/z) 471.28.

\section{Physicochemical parameters of 2-7}

There are studies which suggest some physicochemical parameters such as molar volume $\left(\mathrm{M}_{\mathrm{v}}\right)$ and molar refractory $\left(\mathrm{M}_{\mathrm{R}}\right)$ are chemical tools that corre- late with different biological properties which may depend on the characteristics of each substituent involved in the chemical structure of a molecule. I this investigation, both $M_{V}$ and $M_{R}$ descriptors were determinate using a previously method reported [29]. The theoretical results showed (Table 1) that $\mathrm{M}_{\mathrm{v}}$ and $\mathrm{M}_{\mathrm{R}}$ were higher for 7 compared with 2-6. This phenomenon suggest that steric hindrance, conformational preferences, and internal rotation may be two factors which influence the biological activity exert by 7 on some biological model. However, other type of physiochemical factors such as hydrogen bond donor groups (HBD) and hydrogen bond acceptor groups (HBA), topological polar surface area (TPSA) has been used to predict the biological activity of some compounds in several theoretical models [30].

These physicochemical parameters (Table 1) were determinate using the Spartan 6.0 software; the theoretical data showed that the HBA value was $<10$ and the HBD value was $<5$ for compounds $2-7$, this phenomenon suggest that these compounds may be well absorbed such happening with another type of compounds [31]. Other results showed that polar surface area (PSA) for 2-6 was $<100 \AA$ values; it is noteworthy that some reports suggest that PSA $<140$ $\AA$ values may condition the ability of some drugs to a good oral absorption and exhibit some biological activity [31].

Table 1 - Physicochemical parameters of compounds 2-7. The values were calculated using both ACDLabs and Spartan software

\begin{tabular}{|l|c|c|c|c|c|c|}
\hline \multicolumn{1}{|c|}{ Parameters } & 2 & 3 & 4 & 5 & 6 & 7 \\
\hline Molar Refractivity $\left(\mathrm{cm}^{3}\right)$ & 98.44 & 88.77 & 103.05 & 120.90 & 124.19 & 137.98 \\
\hline Molar Volume $\left(\mathrm{cm}^{3}\right)$ & 279.40 & 269.80 & 307.50 & 359.50 & 375.80 & 371.50 \\
\hline Polarizability $\left(\mathrm{cm}^{3}\right)$ & 39.02 & 35.19 & 40.85 & 47.93 & 49.23 & 54.70 \\
\hline Parachor $\left(\mathrm{cm}^{3}\right)$ & 78.10 & 683.10 & 805.40 & 961.20 & 993.10 & 982.20 \\
\hline Index of refraction & 1.62 & 1.57 & 1.58 & 1.58 & 1.57 & 1.66 \\
\hline Surface Tension $($ dyne/cm) & 57.10 & 41.00 & 47.00 & 51.10 & 48.70 & 48.80 \\
\hline PSA $\AA^{2}$ & 86.58 & 36.04 & 37.97 & 58.49 & 53.46 & 38.44 \\
\hline Density $\mathrm{g} / \mathrm{cm}^{3}$ & 1.28 & 1.15 & 1.26 & 1.21 & 1.19 & 1.26 \\
\hline HBD & 2 & 1 & 0 & 1 & 0 & 0 \\
\hline HBA & 6 & 3 & 4 & 5 & 5 & 4 \\
\hline
\end{tabular}

\section{Pharmacophore evaluation}

This pharmacophore model can furnish a new insight to design novel molecules that can enhance or inhibit the function of the target and will be useful in drug discovery strategies. Therefore, in this study, LigandScout software [14] was used to develop a pharmacophore model of compounds 2 and 3 . The results showed in Figures 4 and 5 indicated that there is a different type of functional groups involved in the compounds 2 to 7 that can interact via hydrophobic contacts or as hydrogen bond acceptors or as hydrogen bond donor with some biomolecules. 


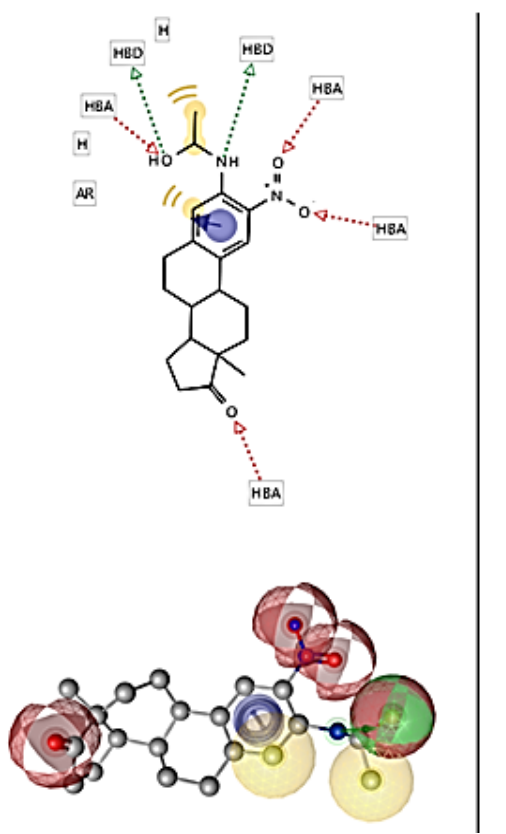

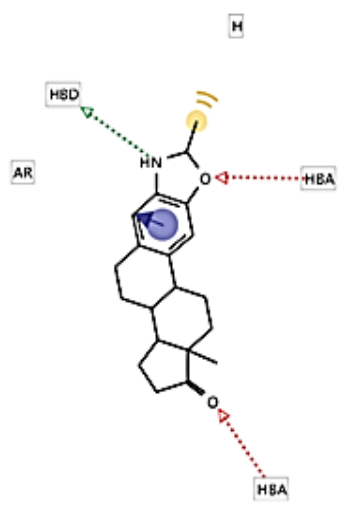

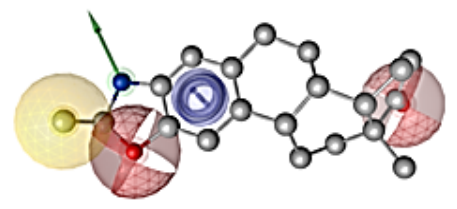

c

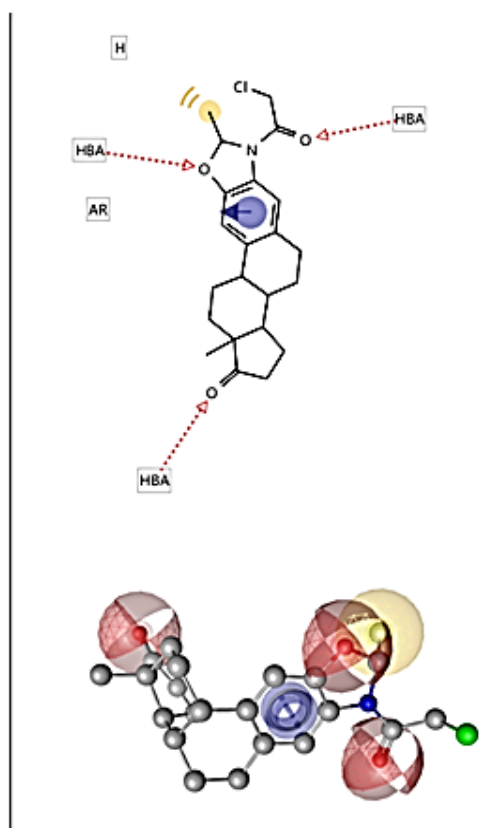

Figure 4 - Scheme represents a pharmacophore from both compounds 2 (A), 3 (B) and 4 (C) using the LigandScout software. The model involves a methyl group (yellow) hydrogen bond acceptors (HBA, red) and hydrogen bond donor (HBD, green)
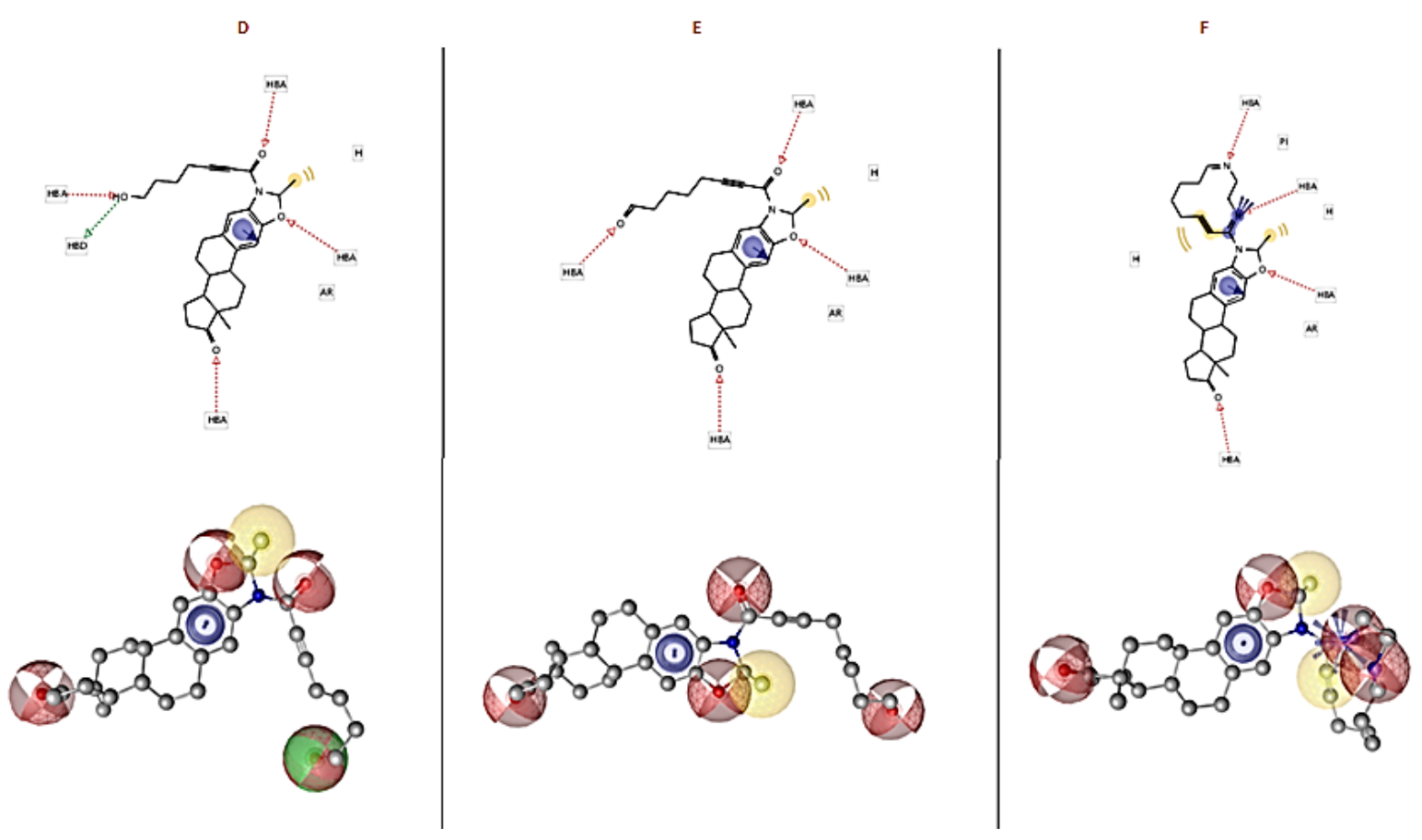

Figure 5 - Theorethical pharmacophore from both compounds 5 (D), 6 (E) and 7 (F) using the LigandScout software. The model involves a methyl group (yellow) hydrogen bond acceptors (HBA, red) and hydrogen bond donor (HBD, green). 
Evaluation of interaction between compounds 2-7 with both COX1-1 and COX-2

Since several years ago, some theoretical models have been used to predict the interaction of some drugs with protein or enzymes [32]. Therefore, in this study was carried out a theoretical analysis on interaction of compounds 7 with both COX1-1 (2OYU) and COX-2 (3LN1) using a Docking model [15] using both indomethacin and Rofecoxib as controls.
I

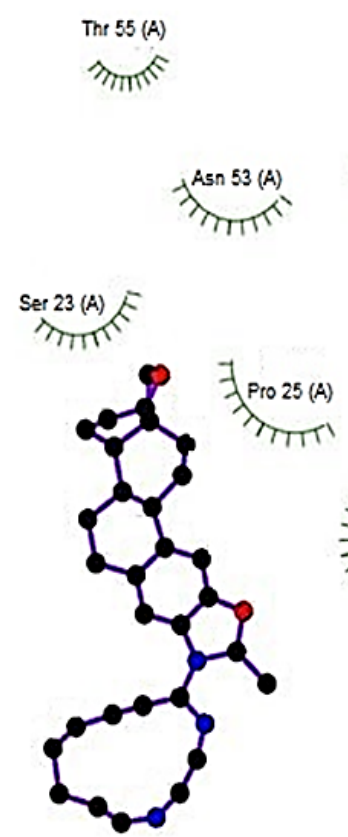

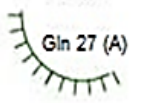

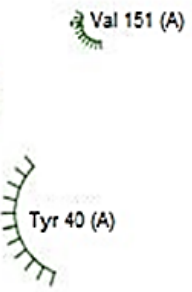

Key

$\underset{\text { Non-ligand bond }}{\longrightarrow}$ Ligand bond

- - Hidrogen bond and its length

H.1. Non-ligand residues involved in other contact (s)

Figure 6 - The scheme shows the binding sites of compound 7 with some aminoacid residues involved on both COX 1 (2oyu [I]) and COX 2 (3LN1 [II]) enzymes.

The visualization was carried out using DockingServer software

The results showed the interaction of both indomethacin and compound 7 were only in two types of amino acid residues involved in the surface of the 2OYU protein, such as $\mathrm{Tyr}_{55}, \mathrm{Pro}_{67}$. Other theoretical data showed a similar interaction between both Rofecoxib and compound 7 with some Ser23, Pro25, $\mathrm{GLn}_{27}, \mathrm{Tyr}_{40}, \mathrm{Asn}_{53}$ amino acid residues of COX-2 (3LN1). All these data suggest that there are differences between the interaction of compound 7 with both COX 1 and COX 2 compared with the bound of indomethacin and rofecoxib with this type of enzymes.
Table 4 - Residue Aminoacids involved in the interaction between both steroid-oxazolone derivative (compound 7) and Indometacin with COX-1 enzyme (2oyu)

\begin{tabular}{|c|c|}
\hline & $\mathrm{Tyr}_{38}$ \\
& $\mathrm{Pro}_{40}$ \\
Steroid-oxazolone derivative & $\mathrm{Tyr}_{55}$ \\
& $\mathrm{Gln}_{156}$ \\
& $\mathrm{Pro}_{67}$ \\
& $\mathrm{Asn}_{68}$ \\
\hline \multirow{2}{*}{ Indometacin } & $\mathrm{Pro}_{35}$ \\
& $\mathrm{Arg}_{54}$ \\
& $\mathrm{Tyr}_{55}$ \\
\hline & $\operatorname{Pro}_{67}$ \\
\hline
\end{tabular}


Table 5 - Residue Aminoacids involved in the interaction between both steroid-oxazolone derivative (compound 7) and Rofecoxib with COX-2 enzyme (3LN1)

\begin{tabular}{|c|c|}
\hline Compound & Aminoacid residues \\
\hline \multirow{3}{*}{ Steroid-oxazolone derivative } & $\mathrm{Ser}_{23}$ \\
& $\mathrm{Pro}_{25}$ \\
& $\mathrm{Gln}_{27}$ \\
& $\mathrm{Tyr}_{40}$ \\
& $\mathrm{Asn}_{53}$ \\
& $\mathrm{Thr}_{55}$ \\
& $\operatorname{Val}_{151}$ \\
\hline & $\mathrm{Ser}_{23}$ \\
& $\operatorname{Pro}_{25}$ \\
& $\mathrm{Gln}_{27}$ \\
& $\operatorname{Tyr}_{40}$ \\
& $\mathrm{Asn}_{53}$ \\
& $\mathrm{Lys}_{152}$ \\
\hline
\end{tabular}

\section{Thermodynamic parameters}

Analyzing the aforementioned data and other types of reports which suggest that the drug-protein interaction could involve other types of intramolecular interactions, in study a theoretical ass was carried out to evaluate some thermodynamic factors involved in the interaction of quinalizarin and the compound 7 with both $2 \mathrm{OYU}$ and $3 \mathrm{LN1}$ proteins such as 1) free energy of binding which determinate the energy value that require a molecule to interact with a protein in a water environment. 2) Electrostatic energy that is the product of electrical charge and electrostatic potential, which are involved in the ligand-protein system; 3) total intermolecular energy and 4) Van der Waals (vdW) + hydrogen bond (Hbond) + desolvation energy (Desolv. Energy; which have an influence on the movement of water molecules into or out of the ligand-protein system) using a theoretical model [15].

The results showed that there are differences in the thermodynamic parameters of compound 7 compared to both indomethacin and rofecoxib. This phenomenon suggests that these differences could be translated as a higher inhibition of biological activity of COX 1 (2OYU) in the presence of compound 7 in comparison with indomethacin. In addition, a lower inhibition of COX 2 (3LN1) with the compound 7 compared with rofecoxib.

Table 6 - Thermodynamic parameters involve in the interaction of both steroid-oxazolone derivative and Indometacin with COX-1 enzyme (2oyu)

\begin{tabular}{|c|c|c|c|c|c|c|}
\hline Compound & $\begin{array}{c}\text { Est. Free } \\
\text { Energy of } \\
\text { Binding } \\
(\mathrm{kcal} / \mathrm{mol})\end{array}$ & $\begin{array}{c}\text { Inhibition } \\
\text { Constant, Ki } \\
(\mu \mathrm{M})\end{array}$ & $\begin{array}{c}\text { vdW + Hbond } \\
+ \text { desolv } \\
\text { Energy }(\mathrm{kcal} / \\
\mathrm{mol})\end{array}$ & $\begin{array}{c}\text { Electrostatic } \\
\text { Energy (kcal/ } \\
\text { mol) }\end{array}$ & $\begin{array}{c}\text { Total Intermol. } \\
\text { Energy (kcal/ } \\
\text { mol) }\end{array}$ & Interact Surface \\
\hline $\begin{array}{c}\text { steroid- } \\
\text { oxazolone } \\
\text { derivative (4) }\end{array}$ & -6.47 & 18.01 & -6.81 & 0.04 & -6.77 & 628.614 \\
\hline Indometacin & -5.32 & 126.53 & -6.24 & -0.19 & -6.43 & 576.698 \\
\hline
\end{tabular}

Table 7 - Thermodynamic parameters involve in the interaction of both steroid-oxazolone derivative and Rofecoxib with COX-2 enzyme (3LN1)

\begin{tabular}{|c|c|c|c|c|c|c|}
\hline Compound & $\begin{array}{c}\text { Est. Free } \\
\text { Energy of } \\
\text { Binding } \\
(\mathrm{kcal} / \mathrm{mol})\end{array}$ & $\begin{array}{c}\text { Inhibition } \\
\text { Constant, Ki } \\
(\mu \mathrm{M})\end{array}$ & $\begin{array}{c}\text { vdW + Hbond } \\
+ \text { desolv } \\
\text { Energy }(\mathrm{kcal} / \\
\mathrm{mol})\end{array}$ & $\begin{array}{c}\text { Electrostatic } \\
\text { Energy (kcal/ } \\
\text { mol) }\end{array}$ & $\begin{array}{c}\text { Total Intermol. } \\
\text { Energy (kcal/ } \\
\text { mol) }\end{array}$ & Interact Surface \\
\hline $\begin{array}{c}\text { steroid- } \\
\text { oxazolone } \\
\text { derivative (4) }\end{array}$ & -6.15 & 30.81 & -6.36 & 0.09 & -6.45 & 673.193 \\
\hline Rofecoxib & -3.78 & 1.69 & -4.90 & 0.18 & -4.73 & 557.621 \\
\hline
\end{tabular}




\section{Conclusions}

These data suggest that the steroid-oxazolone derivative could be a good candidate as $\mathrm{COX}$-inhibitor translated as a possible drug for treatment of pain.

\section{References}

1. Philippe J., Miller D. (2009) Selective and non-selective non-steroidal anti-inflammatory drugs and the risk of acute kidney injury. Pharm Drug Saf. Vol. 18, pp. 923-931.

2. Kearney P., Baigent C., Godwin J., Halls H., Emberson J, Patrono C. (2006) Do selective cyclooxygenase-2 inhibitors and traditional non-steroidal anti-inflammatory drugs increase the risk of atherothrombosis? Meta-analysis of randomised trials. Bmj. Vol. 332, no. 7553, pp. 1302-1308.

3. Amadio P., Cummings D., Amadio P. (1993) Nonsteroidalanti-inflammatory drugs. Postgrad Med. Vol. 93, no. 4, pp. 73-88.

4. Simon L., Milis J. (1980) Non-steroidal antiinflammatory drugs. $N$ Engl J Med. Vol. 302, pp. 1237-1243.

5. Wallace C. (1998) The use of methotrexate in childhood rheu-matoid diseases. Arthritis. Rheum. Vol. 41, no. 3, pp. 381-391.

6. Halis S., Berna D., Yalçin K. (2007) Antiinflammatory and side effects of cyclooxygenase inhibitors. Pharmacol rep. Vol. 59, no. 3, pp. 247-258.

7. Ahmadi A., Khalili M., Hajikhani R., Naserbakht M. (2011) New morpholine analogues of phencyclidine: Chemical synthesis and pain perception in rats. Pharm Biochem Behavior. Vol. 98, no. 2, pp. 227-233.

8. Yogeeswari P., Menon N., Semwal A., Arjun M., Sriram D. (2011) Discovery of molecules for the treatment of neuropathic pain: Synthesis, antiallodynic and antihyperalgesic activities of 5-(4-nitrophenyl) furoic-2-acid hydrazones. Eur j med Chem. Vol. 46, no.7, pp. 2964-2970.

9. Amir M., Kumar H., Khan S. (2008) Synthesis and pharmacological evaluation of pyrazoline derivatives as new anti-inflammatory and analgesic agents. Bioorg Med Chem Lett. Vol. 18, no. 3, pp. 918-922.

10. Elisabetta T., Elisabetta B., Silvia D., Fulvio G., Maria N. R., Serena S., Cristina B., Carla G., Rosanna M. (2004) Design, Synthesis, and Preliminary Pharmacological Evaluation of 4-Aminopiperidine Derivatives as N-Type Calcium Channel Blockers Active on Pain and Neuropathic Pain. J Med Chem. Vol. 47, no. 24, pp. 6070-6080.
11. Cleves A., Jain, A. (2015). Chemical and protein structural basis for biological crosstalk between PPAR $\alpha$ and COX enzymes. J Computer-aided Mol Des. Vol. 29, no. 2, pp.101-112.

12. Figueroa V. L., Diaz C. F., Rosas N. M., Mateu A. V., Montano T. E., Hau H. L., Alfonso J. A. (2019) Design and synthesis of two steroid derivatives from 2-nitroestrone and theoretical evaluation of their interaction with BRCA-1. Asian J Green Chem. Vol. 3, no. 2, pp. 125-287

13. Zakharian T., Coon S. (2001) Evaluation of Spartan semi-empirical molecular modeling software for calculations of molecules on surfaces: $\mathrm{CO}$ adsorption on Ni (111). Comput Chem. Vol. 25, no. 2 , pp. 135-144.

14. Borišek J., Pintar S., Ogrizek M., Grdadolnik S. G., Hodnik V., Turk D., Novič M. (2018). Discovery of (phenylureido) piperidinyl benzamides as prospective inhibitors of bacterial autolysin E from Staphylococcus aureus. J enz inh med chem. Vol. 33, no. 1, pp. 1239-1247.

15. Lin Y. F., Cheng C. W., Shih C. S., Hwang J. K., Yu C. S., Lu C. H. (2016). MIB: metal ionbinding site prediction and docking server. J chem inf mod. Vol. 56, no. 12, pp. 2287-2291.

16. Istrate F., Buzas A., Jurberg D. I., Odabachian Y., Gagosz F. (2008) Synthesis of functionalized oxazolones by a sequence of $\mathrm{Cu}$ (II)-and $\mathrm{Au}$ (I)catalyzed transformations. Org lett. Vol. 10, no. 5, pp. 925-928.

17. Cleaver C., Pratt B. (1995) Synthesis of 2, 2'Bis-[5 (4H)-oxazolones]. J Am Chem Soc. Vol. 77, no. 6, pp. 1544-1546.

18. Yamashita M., Sang H. L., Koch G., Zimmermann J., Clapham B., Janda K. (2005) Solid-phase synthesis of oxazolones and other heterocycles via Wang resin-bound diazocarbonyls. Tetrahedron lett. Vol. 46, no. 33, pp. 5495-5498.

19. Mazurkiewicz R., Pierwocha A. (1996) 4-Phosphoranylidene-5 (4H)-oxazolones-A novel synthesis and properties. Monatsh Chem. Vol. 127, no. 2, pp. 219-225.

[19] Huang H., He G., Zhu G., Zhu X., Qiu S., Zhu H. (2015) Palladium-Catalyzed Intramolecular Cyclization of Ynamides: Synthesis of 4-Halo-oxazolones. J org chem. Vol. 80, no. 7, pp. 3480-3487.

20. Beck J. (1978) Nucleophilic displacement of aromatic nitro groups. Tetrahedron. Vol. 34, no. 14, pp. 2057-2068.

21 Takekoshi T., Wirth J., Heath D., Kochanowski J., Webber M. (1980) Polymer syntheses via aromatic nitro displacement reaction. J Polymer Sci. Vol. 18, no. 10, pp. 3069-3080. 
22. Hiegel G., Hogenauer T., Lewis J. (2005) Preparation of N-Chloroamides Using Trichloroisocyanuric Acid Syn Com. Vol. 35, pp. 2099-2105.

23. Katritzky A., Majumder S., Jain R. (2003) Microwave assisted N-chlorination of secondary amides. Arkivoc. Vol. xii, pp. 74-79.

24. Harte A., Gunnlaugsson T. (2006) Synthesis of $\alpha$-chloroamides in water. Tetrahedron Lett. Vol. 47, no. 35, pp. 6321-6324.

25. Hu Y., Xin X., Wan B. (2015) Cyclization reactions of propargylic amides: mild access to N-heterocycles. Tetrahedron lett. Vol. 56, no. 1, pp. 32-52.

26. Xiao Y. B., Wen W. Z., Qian L., Bi J. L. (2018) Highly Enantioselective Synthesis of Propargyl Amides through Rh-Catalyzed Asymmetric Hydroalkynylation of Enamides: Scope, Mechanism, and Origin of Selectivity. J Am Chem Soc. Vol. 140, no. 1, pp. 506-514.

27. Figueroa V. L., Díaz C. F., García C. E., Pool G.E., Rosas N. M., López R. M., Vera E. I. (2018) Design and synthesis of two triazonine-carb- aldehyde derivatives using several chemical tools. $J$ Saudi Chem Soc. Vol. 22, no.2, pp. 183-197.

28. Figueroa V. L., Diaz C. F., Lopez R. M., Garcia C. E. (2011) Synthesis of pregnenolone-danazolethylendiamine conjugate: relationship between descriptors $\log \mathrm{P}, \pi, \mathrm{Rm}$, and $\mathrm{Vm}$ and its antibacterial activity in S. aureus and V. cholerae. Med Chem Res. Vol. 20, no. 7, pp. 847-853.

29. Bandgar, B., Gawande, S., Bodade, R., Gawande, N., Khobragade, C. (2009). Synthesis and biological evaluation of a novel series of pyrazole chalcones as anti-inflammatory, antioxidant and antimicrobial agents. Bioorg Med Chem. Vol. 17, no. 24, pp. 8168-8173.

30. Pajouhesh, H., Lenz, G. (2005). Medicinal chemical properties of successful central nervous system drugs. NeuroRx, Vol. 2, no. 4, pp. 541-553.

31. Kitchen, D., Decornez, H., Furr, J., Bajorath, J. (2004). Docking and scoring in virtual screening for drug discovery: methods and applications. Nature Rev Drug Discov. Vol. 3, no. 11, pp. 935. 